\title{
Recent advances in understanding frontotemporal
}

\section{degeneration [version 1; peer review: 2 approved]}

\section{Barbara Borroni, Alberto Benussi}

Neurology Unit, Department of Clinical and Experimental Sciences, University of Brescia, Brescia, 25100, Italy

V1 First published: 13 Dec 2019, 8(F1000 Faculty Rev):2098
https://doi.org/10.12688/f1000research.20330.1

Latest published: 13 Dec 2019, 8(F1000 Faculty Rev):2098

https://doi.org/10.12688/f1000research.20330.1

\begin{abstract}
Frontotemporal degeneration (FTD) is a heterogeneous spectrum of neurodegenerative disorders characterized by diverse clinical presentations, neuropathological characteristics, and underlying genetic causes. In the last few years, several advances in the knowledge of clinical and biological aspects have been accomplished and three major scenarios have emerged that will represent the core issues in the FTD scene over the next few years. Foremost, the development of cerebrospinal fluid and blood biomarkers as well as neuroimaging techniques will aid the pursuit of new diagnostic and prognostic markers able to identify the ongoing proteinopathy and predict disease progression, which is key in identifying and stratifying patients for enrolment in clinical trials as well as evaluating response to treatment. On the other hand, current research has focused on the first attempts to slow down or revert disease progression, with the identification of disease modulators associated with disease onset and the ongoing development of the first pharmacological treatments for both sporadic and genetic FTD. Future research will certainly improve our knowledge of FTD and possibly open up a new era of diseasemodifying therapies for this still-orphan disorder.
\end{abstract}

\section{Keywords}

frontotemporal dementia, biomarkers, Tau, TDP43, trials, treatment, diagnosis
Open Peer Review

Approval Status

1

2

version 1

13 Dec 2019

Faculty Reviews are review articles written by the prestigious Members of Faculty Opinions. The articles are commissioned and peer reviewed before publication to ensure that the final, published version is comprehensive and accessible. The reviewers who approved the final version are listed with their names and affiliations.

1. Bradley Boeve, Mayo Clinic, Rochester, USA

2. Pavagada Mathuranath, National Institute of Mental Health and Neurosciences (NIMHANS), Bangalore, Karnataka, India Any comments on the article can be found at the end of the article. 
Corresponding author: Barbara Borroni (bborroni@inwind.it)

Author roles: Borroni B: Conceptualization, Writing - Review \& Editing; Benussi A: Conceptualization, Writing - Review \& Editing Competing interests: No competing interests were disclosed.

Grant information: The author(s) declared that no grants were involved in supporting this work.

Copyright: (c) 2019 Borroni B and Benussi A. This is an open access article distributed under the terms of the Creative Commons Attribution License, which permits unrestricted use, distribution, and reproduction in any medium, provided the original work is properly cited.

How to cite this article: Borroni $B$ and Benussi A. Recent advances in understanding frontotemporal degeneration [version 1; peer review: 2 approved] F1000Research 2019, 8(F1000 Faculty Rev):2098 https://doi.org/10.12688/f1000research.20330.1

First published: 13 Dec 2019, 8(F1000 Faculty Rev):2098 https://doi.org/10.12688/f1000research.20330.1 


\section{Introduction}

Frontotemporal degeneration (FTD) is a highly heterogeneous spectrum of neurodegenerative disorders, not only clinically but also genetically and neuropathologically ${ }^{1}$. This significant heterogeneity has important implications for both diagnostic and therapeutic purposes. Considered in the past as a rare disease, FTD has been clearly shown by recent epidemiological studies ${ }^{2}$ and the refinement of new clinical criteria ${ }^{3,4}$ to be much more frequent than previously thought.

In the last few years, a giant step forward in the knowledge of clinical and biological aspects has been accomplished. Clinically, FTD is characterized by behavioral abnormalities, language impairment, and deficits of executive functions $s^{5,6}$. According to newly revised criteria, three different clinical variants have been defined: the behavioral variant of FTD (bvFTD) $)^{4}$, the agrammatic variant of primary progressive aphasia (avPPA), and the semantic variant of PPA (svPPA) ${ }^{3}$.

One of the most compelling chapters in the recent literature of FTD is represented by the identification of causative mutations responsible for monogenic autosomal dominant disease. Several genetic mutations have been associated with FTD, the most common being those in the microtubule-associated protein tau (MAPT) gene, the granulin $(G R N)$ gene, or the expansion on chromosome 9 open reading frame 72 (C9orf72) gene $^{7,8}$. However, other genes are associated with rare FTD cases, such as valosin-containing protein $(V C P)$ mutations, which are linked to a specific condition called inclusion body myopathy with Paget disease of the bone and FTD (IBMPFD) ${ }^{9,10}$, charged multivesicular body protein $2 \mathrm{~B}(C H M P 2 B)$, which is involved in the endosomal-lysosomal pathway ${ }^{11,12}$, fused in sarcoma $(F U S)^{13,14}$, TAR DNA-binding protein $(T A R D B P)^{15,16}$, sequestosome 1 (SQSTM1) $)^{17-20}$, TANKbinding kinase $1(T B K 1)^{21-24}$, and ubiquilin $2(U B Q L N 2)^{25-27}$.

Along with heterogeneity in both clinical presentations and different autosomal dominant inherited genetic traits, diversified neuropathological hallmarks may be responsible for distinct frontotemporal lobar degeneration (FTLD) diagnoses, which are constituted primarily by tau or TAR DNA-binding protein 43 (TDP-43) depositions ${ }^{28,29}$. Therefore, the critical issue in the current literature of FTD is the lack of a clear-cut relationship between clinical phenotype and neuropathological features. Up to now, the ongoing neuropathological process, and consequently the underlying pathogenetic mechanisms, may be predicted only in monogenic disease. In this case, it is well established that GRN mutations and C9orf72 expansions are associated with FTLD-TDP neuropathology while MAPT mutations are associated with FTLD-Tau ${ }^{30}$. Recent work has also explored the structural and functional neural correlates of behavioral symptoms in FTD. Among these studies, a few have focused on the gray matter correlates of apathy and disinhibition $^{31-34}$, while others have attempted to connect the white matter associations with behavioral symptoms ${ }^{33,35-37}$.

According to these premises, three major scenarios have come out of the recent advances in the field and will represent the core issues in the FTD scene over the next few years. On one hand, the search for diagnostic and prognostic markers able to identify the ongoing proteinopathy in FTD and predict disease progression will be key in identifying and stratifying patients for enrolment in clinical trials. On the other hand, current research has focused on the first attempts to slow down or revert disease progression, with the identification of disease modulators associated with disease onset and the ongoing development of the first pharmacological treatments in a currently considered orphan disorder.

\section{Looking for neuropathology and prognostic markers}

In the past few years, many efforts have been devoted to finding reliable markers which reflect the ongoing neuropathological process in non-genetic FTD. These markers are critical for evaluating potential disease-modifying treatments targeting either tau or TDP-43 pathological mechanisms in homogeneous groups, independently of clinical phenotype, and to better understand the disease pathophysiology $y^{38}$.

$\mathrm{Hu}$ and colleagues proposed the cerebrospinal fluid (CSF) phospho-tau $_{181}$ to total tau (p/t-tau) ratio as a viable biomarker to identify FTLD with TDP-43 pathology as compared to FTLD-Tau, with a reduced ratio suggestive of TDP-43 pathology ${ }^{39}$. These findings have been confirmed in a few subsequent studies in FTD $^{40-44}$, as well as in amyotrophic lateral sclerosis (ALS), which frequently is associated with TDP-43 pathology ${ }^{45}$. Conversely, a recent report investigated novel CSF tau fragments (N-123, N-mid-region, N-224, and $\mathrm{X}-368$ ) in both FTLD-TDP and FTLD-Tau; however, none of the novel tau species showed a significant difference between pathological groups ${ }^{41}$. Similarly, CSF and plasma TDP-43 dosages have not yielded convincing results in differentiating FTLD-TDP from FTLD-Tau ${ }^{46-51}$.

If markers of the neuropathological process are far from being introduced in clinical practice, recent work has identified prognostic markers which will play an important role in forthcoming trials to assess treatment response. Above all, the assessment of neurofilament light chain (NfL), both in CSF and in blood, has recently gained great interest in the field of neurodegenerative disorders, with very high reliability of the assay obtained with advanced technologies ${ }^{52}$. Even though increased NfL levels, reflecting axonal damage, seem to be non-specific for FTD, this marker appears to be a measure of disease intensity and predicts progression and survival ${ }^{44,53-57}$. Longitudinal analysis of samples seems to suggest that levels change not long prior to symptom onset in genetic FTD, increasing by threefold to fourfold during conversion ${ }^{58}$. Thus, a decrease in NfL levels could be a measure of successful disease modification in clinical trials ${ }^{59}$.

Regarding C9orf72 expansion carriers, the putative pathophysiological mechanisms include loss of C9orf 72 function as well as toxicity arising from the accumulation of sense and antisense transcripts of the expanded repeats. These RNA transcripts serve as templates for the synthesis of proteins of repeating dipeptides through repeat associated non-ATG (RAN) 
translation, as poly $(\mathrm{GP})^{60-62}$. Increased CSF poly(GP) levels have been observed in C9orf72 expansion carriers in both the presymptomatic and the symptomatic phase, suggesting that this marker might be altered long before the onset of clinical symptoms and could be useful as a preclinical biomarker in clinical trials in genetic FTD $^{63-65}$.

Concomitantly to biomarker research, positron emission tomography (PET) techniques have paved the way for breakthroughs to assess pathophysiology in vivo in $\mathrm{FTD}^{66}$. In particular, PET imaging of tau burden represents one of the most recent and promising applications in neurodegenerative dementias ${ }^{67}$, and to date a number of tau tracers have been developed, such as $\left[{ }^{18} \mathrm{~F}\right]$ flortaucipir (formerly known as $\left.\left[{ }^{18} \mathrm{~F}\right] \mathrm{AV} 1451\right),\left[{ }^{18} \mathrm{~F}\right] \mathrm{T} 807$, and $\left[{ }^{11} \mathrm{C}\right] \mathrm{PBB} 3{ }^{68,69}$. However, studies of tau radioligands have so far not been proven to be particularly helpful in FTD, binding much more strongly to paired helical filament (PHF)-tau found mainly in Alzheimer's disease $\mathrm{e}^{70,71}$ than to other forms of tau found in the primary tauopathies such as progressive supranuclear palsy ${ }^{72-75}$ or corticobasal degeneration ${ }^{76-78}$. Only two MAPT mutations (V337M and R406W) are associated with PHF-tau and have shown strong binding with $\left[{ }^{18} \mathrm{~F}\right]$ flortaucipir ${ }^{79}$. New-generation tracers are currently under evaluation to overcome the non-specific/off-target binding, as binding has been reported in non-tau diseases such as in $C 9$ orf72 mutation or svPPA, which are mainly associated with TDP-43 pathology ${ }^{80-83}$. Furthermore, the development of PET tracers able to specifically bind $3 \mathrm{R}$ or $4 \mathrm{R}$ tauopathies would have remarkable applications in clinical practice ${ }^{66}$.

Considering that most tau tracers show non-specific/off-target binding with considerable overlap with TDP-43 pathology, the ongoing development of PET tracers specific for TDP-43 aggregates could have significant implications not only for FTD but also for ALS research ${ }^{84}$. These ligands are expected to provide early and more accurate diagnosis of disease, help to monitor disease progression over time, and evaluate whether various therapeutic treatments are having a positive effect in individual patients.

\section{Looking for disease modulators}

Postponing disease onset in FTD is a mandatory issue in the field, especially in presymptomatic individuals carrying pathogenetic mutations. Disease onset is highly variable in each of the genetic forms of FTD, with even intrafamilial variability ${ }^{85}$.

A number of genetic modifiers have been identified in monogenic FTD, thanks to the development of collaborative international multicenter studies, such as GENFI in Europe and in Canada (http://genfi.org.uk) ${ }^{86}$ and ARTFL/LEFFTDS in the US (https://ncrad.iu.edu/index.html) ${ }^{87}$.

In GRN and C9orf72 carriers, the TMEM106B genotype has been clearly associated with age at disease onset ${ }^{88-90}$. Another study of C9orf72 carriers identified two overlapping genes (LOC101929163 and C6orf10) in which a polymorphism was associated with disease onset ${ }^{91}$. The significance of the C9orf72 repeat expansion length remains unclear, with no definitive evidence of an association with age of onset ${ }^{92-97}$. Other genes, such as small G-protein signaling modulator 3 (SGSM3), which is involved in vesicular transport, have been identified as potential disease modifiers in $C 9$ orf 72 carriers $^{98}$. Little is known about factors that modify age at onset in MAPT mutation carriers ${ }^{99}$.

Beyond genetic modifiers that are inherited and immutable, the possibility to intervene with environmental and other modulating factors is attractive. Some evidence shows that cognitive stimulating environments lead to brain volumetrical advantages and better cognitive performances in healthy individuals and in neurodegenerative disorders ${ }^{100}$.

In the same view, in FTD patients, brain reserve, as measured by educational attainment, contributes to resilience against brain damage ${ }^{101-103}$. More interestingly, it has been recently demonstrated that highly educated at-risk subjects, carrying pathogenetic mutations associated with FTD, had better cognition and higher gray matter volume and showed slower loss of gray matter over time ${ }^{104,105}$. Thus, even in the presence of ongoing pathological processes, education may facilitate both brain reserve and brain maintenance in the presymptomatic phase of genetic FTD, virtually turning back the clock of the natural history of the disease. The demonstration that differences in early lifestyle may slow down later disease progression suggests that, even in monogenic disorders, outcomes are not completely determined from birth, and this opens up exciting perspectives for eventually delaying symptom onset $^{104}$.

\section{Disease-modifying therapeutic approaches}

Clinical trial research in FTD spectrum disorders is in its infancy, and there are currently no approved disease-modifying therapies for sporadic or genetic FTD, but trials are now underway or planned for each of the three main FTD genetic mutations $^{99,106}$.

GRN mutations, thought to act through loss-of-function mechanisms, are associated with decreased levels of the protein in serum and $\mathrm{CSF}^{107-109}$. Thus, restoring GRN function by targeting its receptors ${ }^{110,111}$ or increasing protein synthesis is a promising strategy ${ }^{112,113}$. In this view, an emerging target is sortilin, which serves as a lysosomal trafficking receptor for progranulin, and sortilin-mediated progranulin endocytosis has been implicated in FTD pathophysiology ${ }^{114}$. Recombinant human anti-human sortilin monoclonal IgG1 antibodies (AL001) have been developed by Alector and are currently being investigated in a randomized controlled clinical trial (NCT03636204).

Antisense oligonucleotides (ASOs) are short oligonucleotide sequences that can disrupt RNA processing or transduction by activating RNA degradation or preventing ligation with particular RNA-binding proteins ${ }^{115}$. One study in ALS patients found that the ASO drug ISIS 333611 was well tolerated ${ }^{116}$, which suggests that ASOs could be beneficial in neurological disorder treatment ${ }^{117}$. 
Small molecule therapies and tau monoclonal antibodies are also being developed for tauopathies (with the potential for use in MAPT mutations) $)^{118}$. Moreover, tau ASOs are also being planned for MAPT mutation carriers, with the objective of binding to tau messenger RNA and intercepting its translation, lowering the amount of tau protein in the brain. Currently, a clinical trial with a tau ASO (IONIS MAPTRx) is underway in mild Alzheimer's disease (NCT03186989).

The development of new pharmacological interventions and precision-medicine approaches will help to steer clinical trials in FTD spectrum disorders in a productive direction ${ }^{119}$.

\section{Conclusions}

Several advances have been accomplished in recent years in the scenario of FTD. Both CSF and blood biomarkers as well as novel neuroimaging techniques are emerging as promising markers of disease pathophysiology and disease progression. Further effort is needed to identify preclinical biomarkers in the view of innovative clinical trials, in which disease-modifying therapies might need to be administered early in the disease course, as it is becoming clear also for Alzheimer's disease. Indeed, up to now, only CSF and plasma progranulin levels for $G R N$ carriers and CSF poly(GP) dipeptide repeat proteins for C9orf72 expansion carriers seem to be significantly altered long before symptom onset ${ }^{99}$, while neuroimaging abnormalities seem to become discernible about 10-15 years before symptom onset $^{30,120,121}$, as evaluated in large cohorts of patients which may lack single-subject applicability. Emerging neurophysiological techniques such as transcranial magnetic stimulation may be useful in the identification of disease progression, even in the presymptomatic phase of monogenic FTD, long before the onset of clinical symptoms ${ }^{107,122-124}$.

Disease modulators, both genetic and environmental, which play an important role in disease onset and progression, may also become targets of therapeutic clinical trials, inducing modifications in the underlying pathophysiological cascade which results eventually in FTD. In this view, several innovative therapies such as ASOs, small molecules, and monoclonal antibodies are in the pipeline for the treatment of both sporadic and genetic FTD. Future research will certainly improve our knowledge of FTD and possibly open up a new era of diseasemodifying therapies for this still-orphan disorder.

\section{Abbreviations}

ALS, amyotrophic lateral sclerosis; ASO, antisense oligonucleotide; C9orf72, chromosome 9 open reading frame 72; CSF, cerebrospinal fluid; FTD, frontotemporal degeneration; FTLD, frontotemporal lobar degeneration; GRN, granulin; MAPT, microtubule-associated protein tau; NfL, neurofilament light chain; PET, positron emission tomography; PHF, paired helical filament; svPPA, semantic variant of primary progressive aphasia; TDP-43, TAR DNA-binding protein 43.
1. Rademakers R, Neumann M, Mackenzie IR: Advances in understanding the molecular basis of frontotemporal dementia. Nat Rev Neurol. 2012; 8(8): 423-34.

PubMed Abstract | Publisher Full Text | Free Full Text

2. Logroscino G, Piccininni M, Binetti G, et al.: Incidence of frontotemporal lobar degeneration in Italy: The Salento-Brescia Registry study. Neurology. 2019; 92(10): e2355-e2363.

PubMed Abstract | Publisher Full Text

3. F Gorno-Tempini ML, Hillis $\mathrm{AE}$, Weintraub $\mathrm{S}$, et al:: Classification of primary progressive aphasia and its variants. Neurology. 2011; 76(11): 1006-14. PubMed Abstract | Publisher Full Text | Free Full Text | F1000 Recommendation

4. Rascovsky K, Hodges JR, Knopman D, et al:: Sensitivity of revised diagnostic criteria for the behavioural variant of frontotemporal dementia. Brain. 2011; 134(Pt 9): 2456-77.

PubMed Abstract | Publisher Full Text | Free Full Text

5. Neary D, Snowden JS, Gustafson L, et al:: Frontotemporal lobar degeneration: A consensus on clinical diagnostic criteria. Neurology. 1998; 51(6): 1546-54. PubMed Abstract | Publisher Full Text

6. Clinical and neuropathological criteria for frontotemporal dementia. The Lund and Manchester Groups. J Neurol Neurosurg Psychiatr. 1994; 57(4): 416-8. PubMed Abstract | Publisher Full Text | Free Full Text

7. Benussi A, Padovani A, Borroni B: Phenotypic Heterogeneity of Monogenic Frontotemporal Dementia. Front Aging Neurosci. 2015; 7: 171 PubMed Abstract | Publisher Full Text | Free Full Text

8. Borroni B, Padovani A: Dementia: A new algorithm for molecular diagnostics in FTLD. Nat Rev Neurol. 2013; 9(5): 241-2. PubMed Abstract | Publisher Full Text

9. Watts GD, Wymer J, Kovach MJ, et al.: Inclusion body myopathy associated with Paget disease of bone and frontotemporal dementia is caused by mutant valosin-containing protein. Nat Genet. 2004; 36(4): 377-81. PubMed Abstract | Publisher Full Text

10. van der Zee J, Pirici D, van Langenhove T, et al:: Clinical heterogeneity in $\mathbf{3}$ unrelated families linked to VCP p.Arg159His. Neurology. 2009; 73(8): 626-32. PubMed Abstract | Publisher Full Text
11. Holm IE, Isaacs AM, Mackenzie IR: Absence of FUS-immunoreactive pathology in frontotemporal dementia linked to chromosome 3 (FTD-3) caused by mutation in the CHMP2B gene. Acta Neuropathol. 2009; 118(5): 719-20. PubMed Abstract | Publisher Full Text

12. Skibinski G, Parkinson NJ, Brown JM, et al:: Mutations in the endosomal ESCRTIII-complex subunit CHMP2B in frontotemporal dementia. Nat Genet. 2005; 37(8): 806-8.

PubMed Abstract | Publisher Full Text

13. Broustal O, Camuzat $A$, Guillot-Noël L, et al:: FUS mutations in frontotemporal lobar degeneration with amyotrophic lateral sclerosis. J Alzheimers Dis. 2010 22(3): 765-9.

PubMed Abstract | Publisher Full Text

14. van Langenhove T, van der Zee J, Sleegers K, et al.: Genetic contribution of FUS to frontotemporal lobar degeneration. Neurology. 2010; 74(5): 366-71. PubMed Abstract | Publisher Full Text

15. Arai T, Hasegawa M, Akiyama $\mathrm{H}$, et al:: TDP-43 is a component of ubiquitinpositive tau-negative inclusions in frontotemporal lobar degeneration and amyotrophic lateral sclerosis. Biochem Biophys Res Commun. 2006; 351(3): 602-11.

PubMed Abstract | Publisher Full Text

16. F Neumann M, Sampathu DM, Kwong LK, et al:: Ubiquitinated TDP-43 in Frontotemporal Lobar Degeneration and Amyotrophic Lateral Sclerosis. Science. 2006; 314(5796): 130-3.

PubMed Abstract | Publisher Full Text | F1000 Recommendation

17. Le Ber I, Camuzat A, Guerreiro R, et al.: SQSTM1 mutations in French patients with frontotemporal dementia or frontotemporal dementia with amyotrophic lateral sclerosis. JAMA Neurol. 2013; 70(11): 1403-10. PubMed Abstract | Publisher Full Text | Free Full Text

18. F Kovacs GG, van der Zee J, Hort J, et al:: Clinicopathological description of two cases with SQSTM1 gene mutation associated with frontotemporal dementia. Neuropathology. 2016; 36(1): 27-38.

PubMed Abstract | Publisher Full Text | F1000 Recommendation

19. Rubino E, Rainero I, Chiò A, et al.: SQSTM1 mutations in frontotemporal lobar degeneration and amyotrophic lateral sclerosis. Neurology. 2012; 79(15): 
1556-62.

PubMed Abstract | Publisher Full Text | Free Full Text

20. van der Zee J, van Langenhove T, Kovacs GG, et al.: Rare mutations in SQSTM1 modify susceptibility to frontotemporal lobar degeneration. Acta Neuropathol. 2014; 128(3): 397-410.

PubMed Abstract | Publisher Full Text | Free Full Text

21. Freischmidt A, Wieland T, Richter B, et al:: Haploinsufficiency of TBK1 causes familial ALS and fronto-temporal dementia. Nat Neurosci. 2015; 18(5): 631-6. PubMed Abstract | Publisher Full Text

22. Gijselinck I, van Mossevelde S, van der Zee J, et al.: Loss of TBK1 is a frequent cause of frontotemporal dementia in a Belgian cohort. Neurology. 2015; 85(24): 2116-25.

PubMed Abstract | Publisher Full Text | Free Full Text

23. F Pottier C, Ren Y, Perkerson RB 3rd, et al:: Genome-wide analyses as part of the international FTLD-TDP whole-genome sequencing consortium reveals novel disease risk factors and increases support for immune dysfunction in FTLD. Acta Neuropathol. 2019; 137(6): 879-99.

PubMed Abstract | Publisher Full Text | Free Full Text | F1000 Recommendation

24. Pottier $\mathrm{C}$, Bieniek KF, Finch $\mathrm{N}$, et al:: Whole-genome sequencing reveals important role for TBK1 and OPTN mutations in frontotemporal lobar degeneration without motor neuron disease. Acta Neuropathol. 2015; 130(1) 77-92.

PubMed Abstract | Publisher Full Text | Free Full Text

25. F Deng HX, Chen W, Hong ST, et al.: Mutations in UBQLN2 cause dominant X-linked juvenile and adult-onset ALS and ALS/dementia. Nature. 2011; 477(7363): 211-5.

PubMed Abstract | Publisher Full Text | Free Full Text | F1000 Recommendation

26. Fahed AC, McDonough B, Gouvion CM, et al:: UBQLN2 mutation causing heterogeneous X-linked dominant neurodegeneration. Ann Neurol. 2014; 75(5): 793-8.

PubMed Abstract | Publisher Full Text | Free Full Text

27. Synofzik M, Maetzler W, Grehl T, et al:: Screening in ALS and FTD patients reveals 3 novel UBQLN2 mutations outside the PXX domain and a pure FTD phenotype. Neurobiol Aging. 2012; 33(12): 2949.e13-7.

PubMed Abstract | Publisher Full Text

28. F Neumann M, Mackenzie IRA: Review: Neuropathology of non-tau frontotemporal lobar degeneration. Neuropathol Appl Neurobiol. 2019; 45(1): $19-40$.

PubMed Abstract | Publisher Full Text | F1000 Recommendation

29. Spillantini MG, Goedert M: Tau pathology and neurodegeneration. Lancet Neurol. 2013; 12(6): 609-22.

PubMed Abstract | Publisher Full Tex

30. Rohrer JD, Nicholas JM, Cash DM, et al:: Presymptomatic cognitive and neuroanatomical changes in genetic frontotemporal dementia in the Genetic Frontotemporal dementia Initiative (GENFI) study: a cross-sectional analysis. Lancet Neurol. 2015; 14(3): 253-62.

PubMed Abstract | Publisher Full Text | Free Full Text

31. Le Ber I, Guedj E, Gabelle A, et al.: Demographic, neurological and behavioural characteristics and brain perfusion SPECT in frontal variant of frontotemporal dementia. Brain. 2006; 129(Pt 11): 3051-65.

PubMed Abstract | Publisher Full Tex

32. Peters F, Perani D, Herholz K, et al.: Orbitofrontal dysfunction related to both apathy and disinhibition in frontotemporal dementia. Dement Geriatr Cogn Disord. 2006; 21(5-6): 373-9.

PubMed Abstract | Publisher Full Tex

33. F Sheelakumari R, Bineesh C, Varghese T, et al:: Neuroanatomical correlates of apathy and disinhibition in behavioural variant frontotemporal dementia. Brain Imaging Behav. 2019.

PubMed Abstract | Publisher Full Text | F1000 Recommendation

34. F Sheelakumari R, Venkateswaran Rajagopalan, Chandran A, et al:: Quantitative analysis of grey matter degeneration in FTD patients using fractal dimension analysis. Brain Imaging Behav. 2018; 12(5): 1221-8.

PubMed Abstract | Publisher Full Text | F1000 Recommendation

35. Borroni B, Brambati SM, Agosti C, et al:: Evidence of white matter changes on diffusion tensor imaging in frontotemporal dementia. Arch Neurol. 2007; 64(2): 246-51.

PubMed Abstract | Publisher Full Text

36. Hornberger M, Geng J, Hodges JR: Convergent grey and white matter evidence of orbitofrontal cortex changes related to disinhibition in behavioural variant frontotemporal dementia. Brain. 2011; 134(Pt 9): 2502-12. PubMed Abstract | Publisher Full Text

37. Powers JP, Massimo L, McMillan CT, et al: White matter disease contributes to apathy and disinhibition in behavioral variant frontotemporal dementia. Cogn Behav Neurol. 2014; 27(4): 206-14.
PubMed Abstract | Publisher Full Text | Free Full Text

38. Warren JD, Rohrer JD, Rossor MN: Clinical review. Frontotemporal dementia. BMJ. 2013; 347: f4827.

PubMed Abstract | Publisher Full Text | Free Full Text

39. Hu WT, Watts K, Grossman M, et al:: Reduced CSF p-Tau ${ }_{181}$ to Tau ratio is a biomarker for FTLD-TDP. Neurology. 2013; 81(22): 1945-52.

PubMed Abstract | Publisher Full Text | Free Full Text

40. Borroni B, Benussi A, Archetti S, et al:: Csf $\mathbf{p}$-tau ${ }_{181}$ /tau ratio as biomarker for TDP pathology in frontotemporal dementia. Amyotroph Lateral Scler Frontotemporal Degener. 2015; 16(1-2): 86-91.

PubMed Abstract | Publisher Full Text

41. F Foiani MS, Cicognola C, Ermann N, et al:: Searching for novel cerebrospinal fluid biomarkers of tau pathology in frontotemporal dementia: an elusive quest. J Neurol Neurosurg Psychiatr. 2019; 90(7): 740-6.

PubMed Abstract | Publisher Full Text | Free Full Text | F1000 Recommendation

42. F Lleó A, Irwin DJ, Illán-Gala I, et al:: A 2-Step Cerebrospinal Algorithm for the Selection of Frontotemporal Lobar Degeneration Subtypes. JAMA Neurol. 2018; 75(6): 738-745.

PubMed Abstract | Publisher Full Text | Free Full Text | F1000 Recommendation

43. $\mathrm{F}$ Meeter LHH, Vijverberg EG, Del Campo M, et al.: Clinical value of neurofilament and phospho-tau/tau ratio in the frontotemporal dementia spectrum. Neurology. 2018; 90(14): e1231-e1239.

PubMed Abstract | Publisher Full Text | Free Full Text | F1000 Recommendation

44. Pijnenburg YAL, Verwey NA, van der Flier WM, et al.: Discriminative and prognostic potential of cerebrospinal fluid phosphoTau/tau ratio and neurofilaments for frontotemporal dementia subtypes. Alzheimers Dement (Amst). 2015; 1(4): 505-12.

PubMed Abstract | Publisher Full Text | Free Full Text

45. Grossman M, Elman L, McCluskey L, et al.: Phosphorylated tau as a candidate biomarker for amyotrophic lateral sclerosis. JAMA Neurol. 2014; 71(4): 442-8. PubMed Abstract | Publisher Full Text | Free Full Text

46. Bourbouli M, Rentzos M, Bougea A, et al:: Cerebrospinal Fluid TAR DNABinding Protein 43 Combined with Tau Proteins as a Candidate Biomarker for Amyotrophic Lateral Sclerosis and Frontotemporal Dementia Spectrum Disorders. Dement Geriatr Cogn Disord. 2017; 44(3-4): 144-52. PubMed Abstract | Publisher Full Text

47. Feneberg $\mathrm{E}$, Steinacker $\mathrm{P}$, Lehnert S, et al:: Limited role of free TDP-43 as a diagnostic tool in neurodegenerative diseases. Amyotroph Lateral Scler Frontotemporal Degener. 2014; 15(5-6): 351-6.

PubMed Abstract | Publisher Full Text

48. Junttila A, Kuvaja M, Hartikainen P, et al:: Cerebrospinal Fluid TDP-43 in Frontotemporal Lobar Degeneration and Amyotrophic Lateral Sclerosis Patients with and without the C9ORF72 Hexanucleotide Expansion. Dement Geriatr Cogn Dis Extra. 2016; 6(1): 142-9.

PubMed Abstract | Publisher Full Text | Free Full Text

49. Kuiperij HB, Versleijen AA, Beenes M, et al:: Tau Rather than TDP-43 Proteins are Potential Cerebrospinal Fluid Biomarkers for Frontotemporal Lobar Degeneration Subtypes: A Pilot Study. J Alzheimers Dis. 2017; 55(2): 585-95. PubMed Abstract | Publisher Full Text

50. Steinacker $P$, Hendrich $C$, Sperfeld $A D$, et al.: TDP-43 in cerebrospinal fluid of patients with frontotemporal lobar degeneration and amyotrophic latera sclerosis. Arch Neurol. 2008; 65(11): 1481-7. PubMed Abstract | Publisher Full Text | Free Full Text

51. Suárez-Calvet M, Dols-Icardo O, Lladó A, et al:: Plasma phosphorylated TDP43 levels are elevated in patients with frontotemporal dementia carrying a C9orf72 repeat expansion or a GRN mutation. J Neurol Neurosurg Psychiatr. 2014; 85(6): 684-91.

PubMed Abstract | Publisher Full Text

52. $\mathrm{F}$ Bridel $\mathrm{C}$, van Wieringen $\mathrm{WN}$, Zetterberg $\mathrm{H}$, et al:: Diagnostic Value of Cerebrospinal Fluid Neurofilament Light Protein in Neurology: A Systematic Review and Meta-analysis. JAMA Neurol. 2019. PubMed Abstract | Publisher Full Text | Free Full Text | F1000 Recommendation

53. F Alcolea D, Vilaplana E, Suárez-Calvet M, et al:: CSF SAPP $\beta, Y K L-40$, and neurofilament light in frontotemporal lobar degeneration. Neurology. 2017; 89(2): 178-88.

PubMed Abstract | Publisher Full Text | F1000 Recommendation

54. de Jong D, Jansen RW, Pijnenburg YA, et al:: CSF neurofilament proteins in the differential diagnosis of dementia. J Neurol Neurosurg Psychiatr. 2007; 78(9): 936-8.

PubMed Abstract | Publisher Full Text | Free Full Text

55. Meeter LHH, Steketee RME, Salkovic D, et al.: Clinical value of cerebrospinal fluid neurofilament light chain in semantic dementia. $J$ Neurol Neurosurg Psychiatr. 2019; 90(9): 997-1004.

PubMed Abstract | Publisher Full Text | Free Full Text

56. Rohrer JD, Woollacott IO, Dick KM, et al:: Serum neurofilament light chain protein is a measure of disease intensity in frontotemporal dementia. Neurology. 2016; 87(13): 1329-36.

PubMed Abstract | Publisher Full Text | Free Full Text

57. Scherling CS, Hall T, Berisha F, et al:: Cerebrospinal fluid neurofilament concentration reflects disease severity in frontotemporal degeneration. Ann Neurol. 2014; 75(1): 116-26.

PubMed Abstract | Publisher Full Text | Free Full Text

58. Meeter LH, Dopper EG, Jiskoot LC, et al:: Neurofilament light chain: A biomarker for genetic frontotemporal dementia. Ann Clin Transl Neurol. 2016; 3(8): 623-36. PubMed Abstract | Publisher Full Text | Free Full Text

59. F Winter B, Guenther R, Ludolph AC, et al:: Neurofilaments and tau in CSF in an infant with SMA type 1 treated with nusinersen. $J$ Neurol Neurosurg Psychiatr. 2019; 90(9): 1068-9.

PubMed Abstract | Publisher Full Text | F1000 Recommendation

60. F Ash PE, Bieniek KF, Gendron TF, et al.: Unconventional translation of 
C9ORF72 GGGGCC expansion generates insoluble polypeptides specific to C9FTD/ALS. Neuron. 2013; 77(4): 639-46.

PubMed Abstract | Publisher Full Text | Free Full Text | F1000 Recommendation

61. Gendron TF, Bieniek KF, Zhang YJ, et al:: Antisense transcripts of the expanded C9ORF72 hexanucleotide repeat form nuclear RNA foci and undergo repeatassociated non-ATG translation in c9FTD/ALS. Acta Neuropathol. 2013; 126(6): $829-44$

PubMed Abstract | Publisher Full Text | Free Full Text

62. Mori K, Weng SM, Arzberger T, et al:: The C9orf72 GGGGCC repeat is translated into aggregating dipeptide-repeat proteins in FTLD/ALS. Science. 2013; 339(6125): 1335-8.

PubMed Abstract | Publisher Full Text

63. F Gendron TF, Chew J, Stankowski JN, et al.: Poly(GP) proteins are a useful pharmacodynamic marker for C9ORF72-associated amyotrophic lateral sclerosis. Sci Transl Med. 2017; 9(383): pii: eaai7866.

PubMed Abstract | Publisher Full Text | Free Full Text | F1000 Recommendation

64. F Lehmer C, Oeckl P, Weishaupt JH, et al:: Poly-GP in cerebrospinal fluid links C9orf72-associated dipeptide repeat expression to the asymptomatic phase of ALS/FTD. EMBO Mol Med. 2017; 9(7): 859-68.

PubMed Abstract | Publisher Full Text | Free Full Text | F1000 Recommendation

65. Meeter LHH, Gendron TF, Sias AC, et al:: Poly(GP), neurofilament and grey matter deficits in C9orf72 expansion carriers. Ann Clin Transl Neurol. 2018; 5(5): 583-97.

PubMed Abstract | Publisher Full Text | Free Full Text

66. F Perani D, laccarino L, Lammertsma AA, et al:: A new perspective for advanced positron emission tomography-based molecular imaging in neurodegenerative proteinopathies. Alzheimers Dement. 2019; 15(8): 1081-103. PubMed Abstract | Publisher Full Text | F1000 Recommendation

67. Villemagne VL, Fodero-Tavoletti MT, Masters CL, et al:: Tau imaging: Early progress and future directions. Lancet Neurol. 2015; 14(1): 114-24. PubMed Abstract | Publisher Full Text

68. F Okamura N, Harada R, Ishiki A, et al:: The development and validation of tau PET tracers: Current status and future directions. Clin Transl Imaging. 2018; 6(4): 305-16.

PubMed Abstract | Publisher Full Text | Free Full Text | F1000 Recommendation

69. F Tsai RM, Bejanin A, Lesman-Segev O, et al.: ${ }^{18} \mathrm{~F}$-flortaucipir (AV-1451) tau PET in frontotemporal dementia syndromes. Alzheimers Res Ther. 2019; 11(1): 13.

PubMed Abstract | Publisher Full Text | Free Full Text | F1000 Recommendation

70. F Marquié M, Normandin MD, Vanderburg CR, et al:: Validating novel tau positron emission tomography tracer [F-18]-AV-1451 (T807) on postmortem brain tissue. Ann Neurol. 2015; 78(5): 787-800.

PubMed Abstract | Publisher Full Text | Free Full Text | F1000 Recommendation

71. F Schwarz AJ, Yu P, Miller BB, et al.: Regional profiles of the candidate tau PET ligand ${ }^{18} \mathrm{~F}-\mathrm{AV}$ - 1451 recapitulate key features of Braak histopathological stages. Brain. 2016; 139(Pt 5): 1539-50

PubMed Abstract | Publisher Full Text | F1000 Recommendation

72. Ishiki A, Harada R, Okamura N, et al:: Tau imaging with [ ${ }^{18}$ F]THK-5351 in progressive supranuclear palsy. Eur J Neurol. 2017; 24(1): 130-6. PubMed Abstract | Publisher Full Text

73. Passamonti L, Vázquez Rodríguez $\mathrm{P}$, Hong $\mathrm{YT}$, et al.: ${ }^{18} \mathrm{~F}-\mathrm{AV}-1451$ positron emission tomography in Alzheimer's disease and progressive supranuclea palsy. Brain. 2017; 140(3): 781-791.

PubMed Abstract | Publisher Full Text | Free Full Text

74. Schonhaut DR, McMillan CT, Spina S, et al:: ${ }^{18}$ F-flortaucipir tau positron emission tomography distinguishes established progressive supranuclear palsy from controls and Parkinson disease: A multicenter study. Ann Neurol. palsy from controls

PubMed Abstract | Publisher Full Text | Free Full Text

75. Whitwell JL, Lowe VJ, Tosakulwong N, et al.: [ $\left.{ }^{18} \mathrm{~F}\right] \mathrm{AV}-1451$ tau positron emission tomography in progressive supranuclear palsy. Mov Disord. 2017; 32(1): 124-33.

PubMed Abstract | Publisher Full Text | Free Full Text

76. Cho H, Baek MS, Choi JY, et al:: ${ }^{18} \mathrm{~F}-\mathrm{AV}-\mathbf{1 4 5 1}$ binds to motor-related subcortical gray and white matter in corticobasal syndrome. Neurology. 2017; 89(11): 1170-8.

PubMed Abstract | Publisher Full Text

77. Josephs KA, Whitwell JL, Tacik $P$, et al.: [18F]AV-1451 tau-PET uptake does correlate with quantitatively measured $4 R$-tau burden in autopsy-confirmed corticobasal degeneration. Acta Neuropathol. 2016; 132(6): 931-3. PubMed Abstract | Publisher Full Text | Free Full Text

78. McMillan CT, Irwin DJ, Nasrallah I, et al.: Multimodal evaluation demonstrates in vivo ${ }^{18} \mathrm{~F}-\mathrm{AV}$-1451 uptake in autopsy-confirmed corticobasal degeneration. Acta Neuropathol. 2016; 132(6): 935-7.

PubMed Abstract | Publisher Full Text | Free Full Text

79. F Smith R, Puschmann A, Schöll M, et al:: ${ }^{18} \mathrm{~F}-\mathrm{AV}-1451$ tau PET imaging correlates strongly with tau neuropathology in MAPT mutation carriers. Brain. 2016; 139(Pt 9): 2372-9.

PubMed Abstract | Publisher Full Text | Free Full Text | F1000 Recommendation

80. F Bevan-Jones RW, Cope TE, Jones SP, et al.: [ $\left.{ }^{18} \mathrm{~F}\right] \mathrm{AV}-1451$ binding is increased in frontotemporal dementia due to C9orf72 expansion. Ann Clin
Transl Neurol. 2018; 5(10): 1292-6.

PubMed Abstract | Publisher Full Text | Free Full Text | F1000 Recommendation

81. Bevan-Jones WR, Cope TE, Jones PS, et al:: $\left[{ }^{18} \mathrm{~F}\right] A \mathrm{AV}-1451$ binding in vivo mirrors the expected distribution of TDP-43 pathology in the semantic variant of primary progressive aphasia. J Neurol Neurosurg Psychiatry. 2018; 89(10): 1032-7.

PubMed Abstract | Publisher Full Text | Free Full Text

82. Josephs KA, Martin PR, Botha $\mathrm{H}$, et al.: ${ }^{18} \mathrm{FAV}-1451$ tau-PET and primary progressive aphasia. Ann Neurol. 2018; 83(3): 599-611. PubMed Abstract | Publisher Full Text | Free Full Text

83. Makaretz SJ, Quimby M, Collins J, et al.: Flortaucipir tau PET imaging in semantic variant primary progressive aphasia. J Neurol Neurosurg Psychiatry. 2018; 89(10): 1024-31.

PubMed Abstract | Publisher Full Text | Free Full Text

84. Brooks A, Tanzey S, Shao X, et al.: Binding Potential of Radioligand $\left[{ }^{18} \mathrm{~F}\right] \mathrm{FL2}-$ b by Autoradiography in Amyotrophic Lateral Sclerosis and Lewy Body Dementia. J Nucl Med. 2018; 59(supplement 1): 613

Reference Source

85. F Staffaroni AM, Cobigo Y, Goh SM, et al.: Individualized atrophy scores predict dementia onset in familial frontotemporal lobar degeneration. Alzheimers Dement. 2019; pii: S1552-5260(19)30111-6 PubMed Abstract | Publisher Full Text | F1000 Recommendation

86. Rohrer JD, Warren JD, Fox NC, et al:: Presymptomatic studies in genetic frontotemporal dementia. Rev Neurol (Paris). 2013; 169(10): 820-4. PubMed Abstract | Publisher Full Text | Free Full Text

87. Boeve B, Bove J, Brannelly $P$, et al:: The longitudinal evaluation of familial frontotemporal dementia subjects protocol: Framework and methodology. Alzheimers Dement. 2019; pii: S1552-5260(19)35113-1

PubMed Abstract | Publisher Full Text

88. van Blitterswijk M, Mullen B, Nicholson AM, et al:: TMEM106B protects C9ORF72 expansion carriers against frontotemporal dementia. Acta Neuropathol. 2014; 127(3): 397-406.

PubMed Abstract | Publisher Full Text | Free Full Text

89. F van Deerlin VM, Sleiman PM, Martinez-Lage M, et al.: Common variants at 7p21 are associated with frontotemporal lobar degeneration with TDP-43 inclusions. Nat Genet. 2010; 42(3): 234-9.

PubMed Abstract | Publisher Full Text | Free Full Text | F1000 Recommendation

90. Gallagher MD, Suh E, Grossman M, et al:: TMEM106B is a genetic modifier of frontotemporal lobar degeneration with C9orf72 hexanucleotide repeat expansions. Acta Neuropathol. 2014; 127(3): 407-18.

PubMed Abstract | Publisher Full Text | Free Full Text

91. Zhang M, Ferrari R, Tartaglia MC, et al.: A C6orf10/LOC101929163 locus is associated with age of onset in C9orf72 carriers. Brain. 2018; 141(10): 2895-2907.

PubMed Abstract | Publisher Full Text | Free Full Text

92. van Blitterswijk M, DeJesus-Hernandez M, Niemantsverdriet E, et al.: Association between repeat sizes and clinical and pathological characteristics in carriers of C9ORF72 repeat expansions (Xpansize-72): a cross-sectional cohort study Lancet Neurol. 2013; 12(10): 978-88.

PubMed Abstract | Publisher Full Text | Free Full Text

93. Dols-Icardo O, García-Redondo A, Rojas-García R, et al:: Characterization of the repeat expansion size in C9orf72 in amyotrophic lateral sclerosis and frontotemporal dementia. Hum Mol Genet. 2014; 23(3): 749-54.

PubMed Abstract | Publisher Full Text

94. Gijselinck I, van Mossevelde S, van der Zee J, et al:: The C9orf72 repeat size correlates with onset age of disease, DNA methylation and transcriptional downregulation of the promoter. Mol Psychiatry. 2016; 21(8): 1112-24. PubMed Abstract | Publisher Full Text | Free Full Text

95. van Mossevelde S, van der Zee J, Gijselinck I, et al.: Clinical Evidence of Disease Anticipation in Families Segregating a C9orf72 Repeat Expansion. JAMA Neurol. 2017; 74(4): 445-452.

PubMed Abstract | Publisher Full Text

96. $\quad \mathrm{F}$ van Mossevelde S, van der Zee J, Cruts M, et al:: Relationship between C9orf72 repeat size and clinical phenotype. Curr Opin Genet Dev. 2017; 44: $117-24$.

PubMed Abstract | Publisher Full Text | F1000 Recommendation

97. Rutherford NJ, Heckman MG, DeJesus-Hernandez M, et al.: Length of normal alleles of C9ORF72 GGGGCC repeat do not influence disease phenotype. Neurobiol Aging. 2012; 33(12): 2950.e5-7. PubMed Abstract | Publisher Full Text | Free Full Text

98. F Dickson DW, Baker MC, Jackson JL, et al.: Extensive transcriptomic study emphasizes importance of vesicular transport in C9orf72 expansion carriers. Acta Neuropathol Commun. 2019; 7(1): 150.

PubMed Abstract | Publisher Full Text | Free Full Text | F1000 Recommendation

99. F Greaves CV, Rohrer JD: An update on genetic frontotemporal dementia $J$ Neurol. 2019; 266(8): 2075-86.

PubMed Abstract | Publisher Full Text | Free Full Text | F1000 Recommendation

100. Stern Y: Cognitive reserve in ageing and Alzheimer's disease. Lancet Neurol. 2012; 11(11): 1006-12.

PubMed Abstract | Publisher Full Text | Free Full Text

101. Borroni B, Premi E, Agosti C, et al.: Revisiting brain reserve hypothesis in 
frontotemporal dementia: evidence from a brain perfusion study. Dement Geriatr Cogn Disord. 2009; 28(2): 130-5. PubMed Abstract | Publisher Full Text

102. F Maiovis $P$, loannidis $P$, Gerasimou $G$, et al.: Cognitive Reserve Hypothesis in Frontotemporal Dementia: Evidence from a Brain SPECT Study in a Series of Greek Frontotemporal Dementia Patients. Neurodegener Dis. 2018; 18(2-3): 69-73.

PubMed Abstract | Publisher Full Text | F1000 Recommendation

103. F Massimo L, Xie SX, Rennert $\mathrm{L}$, et al.: Occupational attainment influences longitudinal decline in behavioral variant frontotemporal degeneration. Brain Imaging Behav. 2019; 13(1): 293-301.

PubMed Abstract | Publisher Full Text | Free Full Text | F1000 Recommendation

104. Gazzina S, Grassi M, Premi E, et al:: Education modulates brain maintenance in presymptomatic frontotemporal dementia. J Neurol Neurosurg Psychiatr. 2019; 90(10): 1124-30.

PubMed Abstract | Publisher Full Text

105. Premi E, Grassi M, van Swieten J, et al:: Cognitive reserve and TMEM106B genotype modulate brain damage in presymptomatic frontotemporal dementia: a GENFI study. Brain. 2017; 140(6): 1784-91. PubMed Abstract | Publisher Full Text | Free Full Text

106. $\mathrm{F}$ Boxer $\mathrm{AL}$, Gold M, Feldman $\mathrm{H}$, et al.: New directions in clinical trials for frontotemporal lobar degeneration: Methods and outcome measures. Alzheimers Dement. 2019; pii: S1552-5260(19): 35360-9. PubMed Abstract | Publisher Full Text | F1000 Recommendation

107. Benussi A, Gazzina S, Premi E, et al.: Clinical and biomarker changes in presymptomatic genetic frontotemporal dementia. Neurobiol Aging. 2019; 76: 133-40.

PubMed Abstract | Publisher Full Text

108. Finch N, Baker M, Crook R, et al.: Plasma progranulin levels predict progranulin mutation status in frontotemporal dementia patients and asymptomatic family members. Brain. 2009; 132(Pt 3): 583-91. PubMed Abstract | Publisher Full Text | Free Full Text

109. Ghidoni R, Benussi L, Glionna M, et al.: Low plasma progranulin levels predict progranulin mutations in frontotemporal lobar degeneration. Neurology. 2008; 71(16): 1235-9. PubMed Abstract | Publisher Full Text

110. F Tang W, Lu Y, Tian Q-Y, et al:: The growth factor progranulin binds to TNF receptors and is therapeutic against inflammatory arthritis in mice. Science. 2011; 332(6028): 478-84.

PubMed Abstract | Publisher Full Text | Free Full Text | F1000 Recommendation

111. Zheng $Y$, Brady OA, Meng PS, et al.: C-terminus of progranulin interacts with the beta-propeller region of sortilin to regulate progranulin trafficking. PLOS One. 2011; 6(6): e21023. PubMed Abstract | Publisher Full Text | Free Full Text

112. Lee WC, Almeida S, Prudencio M, et al:: Targeted manipulation of the sortilin-progranulin axis rescues progranulin haploinsufficiency. Hum $\mathrm{Mol}$
Genet. 2014; 23(6): 1467-78.

PubMed Abstract | Publisher Full Text | Free Full Text

113. F She A, Kurtser I, Reis SA, et al:: Selectivity and Kinetic Requirements of HDAC Inhibitors as Progranulin Enhancers for Treating Frontotemporal Dementia. Cell Chem Biol. 2017; 24(7): 892-906.e5.

PubMed Abstract | Publisher Full Text | Free Full Text | F1000 Recommendation

114. F Hu F, Padukkavidana T, Vægter CB, et al:: Sortilin-mediated endocytosis determines levels of the frontotemporal dementia protein, progranulin. Neuron 2010; 68(4): 654-67.

PubMed Abstract | Publisher Full Text | Free Full Text | F1000 Recommendation

115. Dias N, Stein CA: Antisense oligonucleotides: basic concepts and mechanisms. Mol Cancer Ther. 2002; 1(5): 347-55. PubMed Abstract

116. F Miller TM, Pestronk A, David W, et al:: An antisense oligonucleotide against SOD1 delivered intrathecally for patients with SOD1 familial amyotrophic lateral sclerosis: a phase 1, randomised, first-in-man study. Lancet Neurol. 2013; 12(5): 435-42.

PubMed Abstract | Publisher Full Text | Free Full Text | F1000 Recommendation

117. Riboldi G, Zanetta C, Ranieri M, et al:: Antisense oligonucleotide therapy for the treatment of C9ORF72 ALS/FTD diseases. Mol Neurobiol. 2014; 50(3): 721-32. PubMed Abstract | Publisher Full Text

118. $\mathrm{F}$ Jadhav $\mathrm{S}$, Avila J, Schöll M, et al:: A walk through tau therapeutic strategies. Acta Neuropathol Commun. 2019; 7(1): 22.

PubMed Abstract | Publisher Full Text | Free Full Text | F1000 Recommendation

119. Desmarais $P$, Rohrer JD, Nguyen QD, et al.: Therapeutic trial design for frontotemporal dementia and related disorders. J Neurol Neurosurg Psychiatry. 2019; 90(4): 412-423.

PubMed Abstract | Publisher Full Text

120. $\mathrm{F}$ Chen $\mathrm{Q}$, Boeve BF, Schwarz CG, et al:: Tracking white matter degeneration in asymptomatic and symptomatic MAPT mutation carriers. Neurobiol Aging. 2019; 83: 54-62.

PubMed Abstract | Publisher Full Text | Free Full Text | F1000 Recommendation

121. $\mathrm{F}$ Chen $\mathrm{Q}$, Boeve $\mathrm{BF}$, Senjem $\mathrm{M}$, et al:: Rates of lobar atrophy in asymptomatic MAPT mutation carriers. Alzheimers Dement (N Y). 2019; 5: 338-346. PublMed Abstract | Publisher Full Text | Free Full Text | F1000 Recommendation

122. Benussi A, Dell'Era V, Cantoni V, et al.: Discrimination of atypical parkinsonisms with transcranial magnetic stimulation. Brain Stimul. 2018; 11(2): 366-373. PubMed Abstract | Publisher Full Text

123. Benussi A, Cosseddu M, Filareto I, et al.: Impaired long-term potentiation-like cortical plasticity in presymptomatic genetic frontotemporal dementia. Ann Neurol. 2016; 80(3): 472-6. PubMed Abstract | Publisher Full Text

124. Gazzina S, Benussi A, Premi E, et al:: Neuroanatomical Correlates of Transcranial Magnetic Stimulation in Presymptomatic Granulin Mutation Carriers. Brain Topogr. 2018; 31(3): 488-497.

PubMed Abstract | Publisher Full Text 


\section{Open Peer Review}

\section{Current Peer Review Status:}

\section{Editorial Note on the Review Process}

Faculty Reviews are review articles written by the prestigious Members of Faculty Opinions. The articles are commissioned and peer reviewed before publication to ensure that the final, published version is comprehensive and accessible. The reviewers who approved the final version are listed with their names and affiliations.

\section{The reviewers who approved this article are:}

\section{Version 1}

\section{Pavagada Mathuranath}

Department of Neurology, National Institute of Mental Health and Neurosciences (NIMHANS), Bangalore, Karnataka, India

Competing Interests: No competing interests were disclosed.

\section{Bradley Boeve}

Mayo Clinic, Rochester, MN, USA

Competing Interests: No competing interests were disclosed.

The benefits of publishing with F1000Research:

- Your article is published within days, with no editorial bias

- You can publish traditional articles, null/negative results, case reports, data notes and more

- The peer review process is transparent and collaborative

- Your article is indexed in PubMed after passing peer review

- Dedicated customer support at every stage

For pre-submission enquiries, contact research@f1000.com 